\title{
Sapo National Park in West Africa: Liberia's First
}

Sapo National Park is the first to be established of three proposed national parks and four nature reserves that were selected in late 1978 and early 1979 with the assistance of IUCN and the World Wildlife Fund. The Park is situated in southeastern Liberia and covers a total land area of $505 \mathrm{sq}$. miles $(1,308 \mathrm{sq} . \mathrm{km})$ of primary lowland rain-forest (Fig. 1). Sapo is 440 miles $(704 \mathrm{~km})$ by road from Monrovia, Liberia's capital city. There are regular local air services from Monrovia to Greenville (lying to the South-West of the Park) and Zwedru to its North.

The new National Park supports many species of large and small mammals which are also distributed throughout the forested regions of the country. Among these are seven species of duikers including rare ones such as Jentink's Duiker (Cephalophus jentinki), Ogilby's Duiker (C. ogilbyi), and the Zebra Duiker (C. zebra). Other mammals include the Bongo (Boccerus euryceros), Pygmy Hippopotamus (Choeropsis liberiensis), Forest Buffalo (Syncerus caffer nanus), and the Forest Elephant (Loxodonta africana cyclotis). More than ten species of primates are found in Sapo: these include Chimpanzee (Pan troglodytes), Western Black and White Colobus monkeys (Colobus spp.), the Diana Monkey (Cercopithecus diana), as well as smaller species such as galagos (Galago spp.) and Pottos (presumably Perodictus potto). Many species of reptiles and approximately 300 species of birds also inhabit Sapo.

The Park is currently protected by a staff numbering twenty-two. Four of these are trained Liberian graduates of the College of African Wildlife Management in Tanzania, two are US Peace Corps volunteers, and the

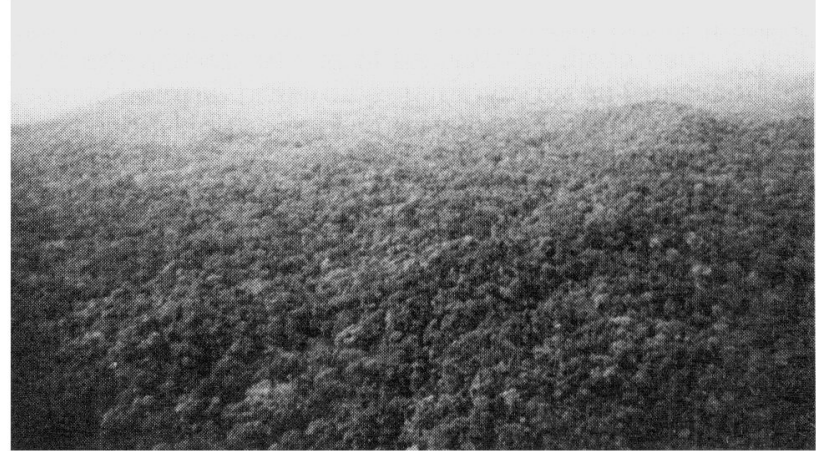

FIG. 1. Aerial view of Sapo National Park, Liberia, showing the undulating terrain and covering of rain-forest.

others are ex-hunters or farmers who are well-acquainted with the forest environment in that part of the country.

The official establishment of Sapo National Park in May 1983 was a major breakthrough for wildlife conservation practices in Liberia, and its development may stimulate the creation of the other national parks and nature reserves. Emphasis in the early management of the Park is being placed on research into the biological resources of the region, under the direction of the Forestry Development Authority.

Division of Wildlife and NATIONAL PARKS
Forestry Development Authority
P.O. Box 3010
Monrovia
Republic of Liberia.

Division OF Wildlife and NATIONAL PaRks P.O. Box 3010

Republic of Liberia.

\section{Global Conservation for Wandering Wildlife}

An international agreement to protect migratory wild animals has passed a final hurdle and will enter into force shortly, the International Union for Conservation of Nature and Natural Resources (IUCN) announced on 1 November 1983. The Bonn Convention on the Conservation of Migratory Species of Wild Animals was concluded in 1979 , but could not operate until 15 states or groups of states had formally ratified or acceded to it. On 1 September 1983, Italy became the fifteenth: after the required three-months' period of notice, the Convention therefore enters into force on 1 December 1983.

Many endangered animals, such as the Mountain Gorilla (Gorilla gorilla beringei), the Blue Whale (Megaptera novaeangliae), Grevy's Zebra (Doliochohippus grevii), and the Siberian Crane (Grus leucogeranus), have no fixed abode but migrate across national boundaries. The efforts of all states concerned are thus necessary for their conservation, and this can only be arranged through an international convention.

Other migratory species not actually regarded as endangered could soon become so if their safety or freedom of movement were set at risk in any part of their range, no matter how carefully they were protected elsewhere. Examples are the Beluga or White Whale (Delphinapterus leucas), the Vicuna (Vicugna vicugna), the Dugong (Dugong dugong), various falcons, Ospreys (Pandion haliaeetus), certain cranes and ducks-also the Monarch Butterfly (Danaus plexippus) and the Saltwater Crocodile (Crocodylus porosus).

The Bonn Convention requires its contracting parties to protect the designated migratory endangered species now at large in their territory as an immediate priority and, in the longer term, to make arrangements with other governments to protect listed species - endangered or not-which visit both or all of their territories.

IUCN assisted the Federal Republic of Germany in drafting the Convention. The World Wildlife Fund provided a substantial part of the funds required for this exercise. For the present, implementation will be managed by the Federal Republic of Germany until a Scientific Council and a regular Secretariat are formed to press on with the Convention's full activation. IUCN is prepared to play a major role in this process.

Already in force are conventions regulating trade in endangered wild species of plants and animals (CITES), protecting wetlands (Ramsar Convention), and setting aside sites of special natural or cultural importance (World Heritage Convention).

The fifteen initial members of the Bonn Convention are the EEC plus Cameroon, Chile, Denmark, Egypt, Hungary, India, Ireland, Israel, Italy, Luxembourg, Netherlands, Niger, Portugal and Sweden-a mixture which is representative enough to provide an excellent example to other states that should join their ranks in due course. 